\title{
Crisis and Reconciliations of Whites after Flourishing Hegemony in Post-Apartheid Era: Projection on Coetzee's Disgrace
}

\author{
Shayla Akter* \\ Lecturer, Dept. of English. Pabna University of Science and Technology, Bangladesh.
}

*Corresponding Author: Shayla Akter, Lecturer, Dept. of English. Pabna University of Science and Technology, Bangladesh.

\begin{abstract}
Disgrace a famed, novel by award-winning Nobel laureate, John Maxwell Coetzee, gleams a disturbing scenario of the state of Post-apartheid South Africa. The novel mainly radiates on the changing situation of power shifting to black majority rule, the sufferings, hardship, losing supremacy of whites in South Africa after apartheid era. Disgrace comments upon the whites and the blacks untiring attempt to coexist harmoniously where whites undergoing predicaments, deterioration, anxieties but as commune want to reconcile to get rid of their previous dominant supreme hegemony in apartheid era. All things were changed after the ending of racial segregation in 1994. The white settlers are even ready to surrender their over lordship politically. Under these circumstances they became timid and failed to protect their land, security, became disrespected and distrusted. The present article would projects on the Chronological anxieties of whites' during the transforming of power but eventually subjugated owing to live peacefully under the flourishing hegemony of Post-apartheid era. The paper also zooms in the conditions of surviving in Post- apartheid South Africa through bending, sacrificing, taming, reconciling to search for a new way to coexist.
\end{abstract}

Keywords: Post-apartheid, Deterioration, Hegemony, Subjugate, Reconcile, Coexist.

\section{INTRODUCTION}

The images of white's crisis in Post-apartheid South Africa have been portrayed commendably in laudable novel Disgrace. It mainly focuses on the reckless reconciliation of the blacks and the whites and their sufferings during the Post-apartheid period in South Africa after the blacks having backed their power, long declined freedom, domination which they were declined for centuries. "PostApartheid refers to the period in South Africa after the end of Apartheid, which was the policy of "separateness" or the legally enforced separation of the races. It dates from 1994 to the present" (Assefa, et all 3).It gives a ponderous sketch regarding whites struggle and reveals their torment to adapt with the new formed atmosphere during Post-Apartheid time. In this paper we will observe that after humiliating, suffering a lot, how the protagonist characters, David Lurie and his daughter, Lucy Lurie struggled to adapt to the changing situation. They could anticipate that reconciliation is only possible when they will be subjugated.

\section{Crisis ANd Reconciliations of Whites AfTer Flourishing Hegemony}

The whites always maintain structural advantage in every sphere of life and educational advantage is one of the dominant traits of that. The white male protagonist David Lurie, a discredited university professor who instructed English Literature and Communication Skills in Cape Technical University is a bright example behind this thought. Thinking himself an extraordinarily a learned, high positioned made him obstinate regarding surrounding perspective during the Post-apartheid time. Lucy Lurie, the daughter of him attains quite a reverse character from his father, is a much tolerable, laborious and self- reliant young girl. Both of them became the victim of blacks' tyranny or revenge.

As the novel begins readers are introduced to David Lurie, a twice-divorced professor who rambles the brothel to mitigate his indomitable carnal appetite. After the divorce he feels "he has solved the problem of sex rather well" (Coetzee 1).To fulfill his biological urge he drives to Windsor Mansions to relish "honey-brown body" (1) Soraya. The authoritative attitude of Lurie reveals when he forbade 
him to wear vermilion lipstick and heavy eye shadow. "Not liking the stickiness of the makeup, he asked her to wipe it off. She obeyed and never wore it since" (5).As a quick learner she, very submissively obeyed his wish to content him, to content a client. This attitude reveals the dominant white supremacy which Lurie is used to practice consecutively and successfully. Suddenly after being refused by Soraya he allured his new prey, a non western South African black, Melanie Isaacs, one of his students. Through exercising power, without her consent he pushed her into having copulation with him and manipulates him. "She does not resist. All she does is avert herself: avert her lips, avert her eyes" (25). It is very reproachful that he took advantage of helpless, young student of him. As a womanizer Melanie could not escape herself from his profligate gripe. After being exposed to his dalliance, an unexpected occurrence happened to him. He was confident enough to handle the situation by taking Melanie under his control but he failed. Melanie lodged a file and started a fight back against her abuser on grounds of abuse sexually. In a committee of inquiry he was offered to confess but he rejected to do so and to defend he says, "I was not myself ..... I became a servant of Eros" (52). Lurie cannot resist his emotion and Melanie became the scapegoat here. "It was far from Ungovernable"(52).He tried to justify his statement like "Just an impulse he could not resist, with no mention of the pain he has caused, no mention of the long history of exploitation of which this is part"(53). The extract shows Lurie's concoction about establishing his blind notion through his own actions. "Repentance is neither here nor there. Repentance belongs to another world, to another universe of discourse" (58). As he didn't confess his crime so doesn't think about the repentance. He was surrounded by his own concocted philosophy and will not confess his own philosophy or private thoughts to the inquisitors. The ultimate defiance before committee we see as he says:

"Now we are truly splitting hairs.You charged me, and I pleaded guilty to the charges .That is all you need from me."

"No we want more. Not a great deal more but more. I hope you can see your way clear to giving us that."

“Sorry. I can’t."(58)

Above lines which were taken from the conversation between Lurie and Manas, projects the consecutive pressure about confessing guilt and to repent for his dalliance but very definitely he refuses confessing guilt, to apologize publicly and resigns from his job. $\mathrm{He}$ is given plenty of opportunity to express penance, entering counsel and guard his job, but he staunchly rejects. As if he purposefully wishes to devastate himself instead of stooping.

His profligacy with Melanie started to spread blatantly, and became a reason for public outrage. $\mathrm{He}$ was harassed by Melanie's boyfriend, distrusted to his students, became an object point of agitation, his car vandalized. Leaving Cape Town he then moves to his daughter, Lucy's isolated smallholding in the town of Salem in the Eastern Cape to live there for a while. We tend to feel that Lurie's life was going from bad to worse in every sphere.

Lucy, a self-contained girl, lives alone on her farm running a small kennel, raising and selling flowers and crops. Lucy, a reliable person to whom he can unburden himself by sharing his own feelings.

"Roz said the atmosphere was

nasty.'

'I bought it on myself. I was offered a compromise, which I wouldn't

accept.'

'What kind of compromise?'

'Re-education. Reformation of the character. The code- word was counseling.'

$\cdots$

'So you stood your ground and they stood theirs. Is that how it was?'

'More or less.'

'You shouldn't be so unbending, David. It's not heroic to be unbending. Is there still time to reconsider?' 
No the sentence is final."'(66)

Lucy thinks that to be unbending is not a wise decision in the current situation and suggests him to rethink but again imprudently he inhibited. "Every woman I have been close to has taught me something about myself. To what extent they have made me a better person" (70).Company of Lucy actually started to spiritualize him as they had an inverse ideology of life. About Lucy's ideology we can mention the renowned scholar Derek Attridge's view of ethics. This way of the writing was showing respect to the other; he thinks that being ethical means "being responsible for the other and assuming the other's needs, affirming them, sustaining them, being prepared to give up my own wants and satisfactions for the sake of the other" (Attridge 124). The living life could be cozier but she settled here here due to tracing the beauty of country life. She is officious to always give her hand to her friends. But David, having accustomed with city life, country life was boring to him but Lucy's contiguity through difficulty started adjusting to the life of farm and soon reluctantly diffuses him at a local animal refuge as well as helping Lucy on the farm. Built a friendship with the assistant, Petrus, black neighbor of Lucy. Life was going good through tranquility.

The tranquility was as transient as the ignition of the power balancing also shifts in the country. As we find in Leonard's view "African murdered whites on isolated farms in the North,... Property was in jeopardy in some areas" (Leonard 267). He and Lucy became prey of a serious disaster that fell victims to a savage attack by three black men during which Lucy was raped and Lurie was badly wounded. After this incident Lurie tries to console like "It happens every day, every hour, every minute, he tells himself, in every quarter of the country. Count yourself lucky to have escaped with your life" (Coetzee 98). The great scholar Leonard Thompson in his book, the history of South Africa wonderfully explained about the turmoil of South Africa. "South Africa was an exceptionally violent society. Whereas in previous generations Whites had a near monopoly of firearms, -by 1994 South Africans of all races owned modern weapons" (Leonard 267).

Lucy, undergoing gruesome experience turned depressed and lost all the heed from earthly deed for a while. She is hurt and more stunned about the extreme hatred of perpetrators. "It was done with such personal hatred........... But why did they hate me so? I had never set eyes on them" (156).The offenders even didn't exempt the dogs inside the kennel, devastated the house stealing valuables with Lurie's car. Lucy reports to the police about the robbery and her father's attack but hid of her own outrage. Even forbade her father to reveal the oppression that happened to her to neighboring people. "while seeing as a victim of an injustice that decrees her to be a criminal incitement of herself, she still feels dirtied and humiliated" (Beauvoir 545).

Lurie was upset about acquiescing to Lucy's situation where she is the oblation. As Lucy was very pragmatic to realize the clutter judicial system of South Africa she doesn't expect any fair play. But Lurie fails to realize that the "the place being South Africa", "the police are not going to save" them $(112,100)$. After the incident Lucy became depressed, taciturn and Lurie felt "It will be like to be an old man, tired to the bone, without hopes, without desires, indifferent to the future" (107).Lurie thought Lucy is taking the burden upon her to expiate of their ancestral crime and the decision of taciturnity is nothing but some form of private salvation. Despite Bev's counsel, despite petrus's assurance and despite Lucy's obstinacy he is not prepared to abandon his daughter in such a miserable situation. "time does indeed heal all" (141).He is wishing heartily that Lucy will be able to heal soon. Leaving Lucy in her own state reluctantly he retreats in Cape Town and pondered over Melanie again. Observing the wretchedness of Lucy now he felt the situation of Melanie and his family. Getting rid of psychological warfare he finally bended, apologized. "For which I am sorry. I am sorry for what I took your daughter through. You have a wonderful family. I apologize for the grief I have caused you and Mrs. Isaacs. I ask for your pardon............. „So says Isaacs, "at last you have apologized" (171).Through apologizing he unburdened himself, got salvation from inner conflict. "I am being punished for what happened between myself and your daughter .I am sunk into a state of disgrace from which it will not be easy to lift myself" (172).

Lurie, who is now conscious enough failed actually to untroubled the honor of both him and his daughter, Lucy as because the supremacy of whites fell down and the blacks became powerful. 
Situation became more intricate after revealing the pregnancy of Lucy and one of the offenders' identities. None but Petrus's relative and Petrus appeared as the Patronizer of that culprit. As the blacks are now the majority rule their voice is also louder and confident. When Lurie threw a question about lying, Petrus defends in a very naked way. "I lie to you ......." you come to look after your child. I also look after my child". He is my family, my people" (201). Very consciously Petrus differentiates between the races. Once Lucy, who was benefactor, now turns into a rival. The black men see themselves as debt collectors, tax collectors and Lucy owe something in return she should be paid. She established her living here, cleared her debt of ancestors through surrendering her body. According to Foucault, "When power is inverted, it greatly affects the psychology of those who exercised or manipulated it before. On the other hand those who achieved it newly at the cost of blood are willing to use it as a mean of revenge for their life-long suppression" (Ruman 12).It was always penetrating Lucy become an outsider in her own land so this time she decides handing over all the property, land and all her rights to Petrus. When David asks about humiliation, sudden fall from the zenith to the nadir like starts with a big hope and end with nothing, says faintly:

"Yes, I agree, it is humiliating. But perhaps that is a good point to start from again. Perhaps that is what I must learn to accept. To start at ground level. With nothing .Not with nothing but. With nothing. No cards, no weapons, no property, no rights, no dignity.'

\section{'Like a dog.'}

$$
\text { 'Yes, like a dog." (205) }
$$

The reason behind such taciturnity and humbly are nothing but powerlessness. She knows if she wants to live on the farm she has to endure all the barbarity and humiliation. "In the new scenario the former oppressed races affirm their voice to the scope of silencing the whites. The country is passing through an immense reshuffling of social relations"(Koul 182).Lucy pays a great penalty to be sheltered by Petrus as though she knows that Petrus' proposal for marriage is nothing but a trick to grab her land under the shade of security, she consents to be his concubine. Petrus becomes a strong example of power inversion as a man attained all the power and the property of a white, turns himself from coproprietor to proprietor, from an care-taker to landowner. "Masculine on the whole, those who fashioned it, ruled it and still dominate it today are men" (Das 94)

During Post-apartheid period, land transformation is one of the significant sections for power exercising for both blacks and the whites. Knowing the consequence Lucy sacrifices all only for a security, safe shelter where losing everything in return just wants reconciliation in her own land like a tenant but to ahead in life peacefully through reconcilability. She is "prepared to do anything, make any sacrifice, for the sake of peace" (Coetzee 208). According to Said, morality is the most superior thing. If you want to conquer then do it ethically. "The basic legitimating of conquest over native peoples is the conviction of our superiority, not merely our mechanical, economic, and military superiority, but our moral superiority" (Said 17).

\section{CONCLUSION}

Coetzee has sketched the changing situation occurred during the post-apartheid time, comments upon their untiring attempt where the black and white people struggled a lot for their peaceful coexistence. After the disintegration of white's domination, losing power, their predicaments, being dominated and violated extremely by blacks who got back their long lost freedom. David Lurie and Lucy Lurie's sacrifice, subjugation in a desperate way to hold their root, identity after being tortured symbolized their silent submission under flourishing hegemony. Living life like a dog, Lucy shows us the best way of being in this world. After being brutalized, humiliated being stooped, surrendered reveals their formidable eagerness to reconcile peacefully under a challenging atmosphere, flourishing hegemony.

\section{REFERENCES}

[1] Abrams MH, (2001). A Glossary of Literary Terms. A Harcourt Publishers International Company (7 $7^{\text {th }}$ ed).

[2] Assefa DT and Chernet YA. (2018). Disintegration of White Supremacy in the Novel Disgrace by Coetzee after the End of Apartheid System in South Africa. J Pol Sci Pub Aff 6: 333. doi:10.4172/2332 0761.1000333 
[3] Attridge, Derek. (2004), the singularity of literature. London: Rutledge.

[4] Beauvoir, Simon de. (2011). the second sex .Trans and Ed. Constance Borde and Sheila Malovany Chevallier. London: vintage.

[5] Coetzee J. M. (2000). Disgrace. London: Vintage.

[6] Das, Bijay Kumar. (2012). Twentieth Century Literary Criticism. ${ }^{6}$ th ed. New Delhi: Atlantic Publishers \& Distributions (P) Ltd.

[7] Koul, Indu. (2016). Racial Complexity: A Dilemma in J.M. Coetzee's Disgrace. Pune Research Times: An . J Contemporary Stud.

[8] Ruman, Abdul Karim.(2013). Power, Colonization and Racism in Nadine Gordimer's July's People. Bangladesh Research Foundation Journal.

[9] Said, Edward W.(1004). Cultural and Imperialism. London: Vintage.

[10] Thompson, Leonard. (2001)The History of South Africa. New Haven, CT: Yale University press UN's conventions.

\section{AUTHOR'S BIOGRAPHY}

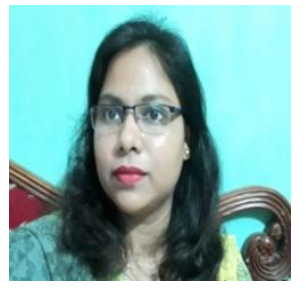

Shayla Akter, Lecturer, Dept. of English. Pabna University of Science and Technology, Bangladesh.

Citation: Shayla Akter. Crisis and Reconciliations of Whites after Flourishing Hegemony in Post-Apartheid Era: Projection on Coetzee's Disgrace "International Journal on Studies in English Language and Literature (IJSELL), vol 8, no. 3, 2020, pp. 1-5. doi: http://dx.doi.org/10.20431/2347-3134.0803001.

Copyright: () 2020 Authors. This is an open-access article distributed under the terms of the Creative Commons Attribution License, which permits unrestricted use, distribution, and reproduction in any medium, provided the original author and source are credited. 